\title{
A New Framework To Revive Industries With The Help Of Advanced Technology Used As Marketing Tool
}

\author{
Ishan Bhatt ${ }^{1}$, Dr. Rushina Singhi ${ }^{3}$ \\ ${ }^{1}$ Amity University, Noida, Uttar Pradesh, India(201311) \\ ishanbhatt.korba@gmail.com \\ ${ }^{21}$ Amity University, Noida, Uttar Pradesh, India(201311) \\ rsinghi@amity.edu
}

\begin{abstract}
Entire world is facing a huge competition in the market. Companies are spending tremendously over marketing of products and services. These costs are taking a toll on profit as well. Many industrial units are facing loses and banks are getting cash deficit. In order to revive market, it is necessary to understand new consumer approaches and behaviour to identify their buying pattern. Clearly lesser profits and increasing marketing cost are signs of down trend. There are many types of consumer behaviour theories. They have their own advantages but they also contain serious flaws. These flaws make them vulnerable. This paper proposes to discover a new consumer behaviour or perspective of millennials. This will help in increase of profits and decrease marketing costs. The framework will also help in reducing operational cost, human resource costs and distribution cost all together.
\end{abstract}

Keywords- upcoming consumer behaviour trend, digital sophisticates, digital enthusiasts, marketing for millennials

\section{Chapter 1. Introduction}

For years companies have been using various methods for promoting their products and services. Marketing is a tool that bridge the gap between an uninformed consumer and a product manufacturer. From past many years, there has been several industrial sectors which have grown and then declined due to various reasons. Traditionally a product life cycle and industry life cycle has been designed which is comprised of four stages. All these four stages have their different marketing strategies, pricing strategies, market penetration strategies, product diversification strategies, market diversification strategy, etc. However, there has been very little research being done on what a company should do after the decline phase.

Rise of technology and digital world has given many sectors a new opportunity to increase their revenues and once again restore consumers attention and needs. Due to cutting edge technologies and advanced algorithms it is now very easy to target niche market and increase companies' revenue using artificial intelligence, robotics and drone systems. It is obvious that not every company is capable of using high tech and also it is not made for every type of consumer base. As the world population has been increasing at a tremendous rate and everybody wants to take a slice of a pie. I propose an "engineering used as marketing" framework which will help various companies to re-establish their market position and enhance industrial growth even after the product has reached the decline phase of product life cycle curve. This study will involve various market penetration strategies, consumer behaviour and technological aspect.

Technological enthusiasts have been increasing at a tremendous rate. Technology is now a part of premium factor added to a product or service. Even after the decline phase company can divest some of its resources and can re-invest that money in research and development of various Hi-Tech features added to their products. This will not only create a huge public attention of digital enthusiasts and digital sophisticates but also increase premium factor to the product. This premium factor will increase the revenues and aid in gathering return of investment which was initially used for research and development. Not many companies have been practicing this strategy but as the number of digital enthusiasts and sophisticated have been increasing at a tremendous rate with a CAGR of $16.4 \%$, it is very obvious that the same strategy will be very useful for upcoming generation.

There are many products and services which were initially designed for $\mathrm{X}$ and $\mathrm{Y}$ generations however they became too old for generation $\mathrm{Z}$. In order to revive those industries, we have to combine the unique features of this age with the features of the older ages and create a new product. Because industries are combining equipment and software with their products, this will be very much profitable with respect to porter's five model. As according to Porter's five force model an industry should have a smaller number of competitors and restrict the entry of new entrants. This will surely help them in this way.

From thousands of years, economy of country is entirely dependent upon manufacturing and service providing companies. There are many different types of products and services available in the market however not every product and service are capable of creating a unique mark on the basis 
Website: ijetms.in Issue:4, Volume No.4, July-2020 DOI: 10.46647/ijetms.2020.v04i04.001

of revenues. The simple reason behind this problem is lack of marketing. Marketing is a bridge between company and the consumers. It attempts to create an awareness for education among the customer and emphasize them to adopt a particular product or service that will enhance their way of living. Naturally marketing trend keeps on changing at a very faster rate because of problem-solving or need fulfilling capacity a product or service holds. It is very important to do market segmentation and identify consumer psychology. This study is known as consumer behaviour. Consumer behaviour is based on principle of 'need'. It States that need drives a consumer to buy a certain product or service.

Consumer behaviour keeps on changing and in the current world this is rate of change has gone even at a faster rate. India with 1.3 billion consumers, have different types of needs and it is essential for a marketer to anticipate those needs and create a product/service that will fulfil their needs. It is essential to predict consumer behaviour in advance so that companies could gather insight from that research and can make better product/ service. This project attempt to analyse a new consumer behaviour in which advanced technological system creates an intent to buy. Till now very less research has been conducted in this field. I attempt to prove that investing in new technology will surely be a game changer for manufacturing as well as marketing aspect of a business.

Higher technological advancements create an opportunity to reduce manufacturing cost and it also creates a desire in consumers to buy. This is a very common psychology of digital enthusiast. With limited amount of natural resources(such as coal, petrol and diesel), it is becoming difficult for companies to serve their consumers with high quality product but with the help of advanced technology and cutting-edge algorithms this problem can be solved easily.

\section{Chapter 1.1 Printing Press and Kindle}

To understand this concept, Let us consider a very unique product known as Kindle. It was manufactured by Amazon.inc. Amazon is an American based company which provides an E-Commerce platform to buy products and services. It is a billion-dollar company which invested in Kindle. Kindle is an E-Commerce platform for books, novels, educational journals, newspapers and magazines.

With the help of cloud computing and advanced technology they managed to create a Kindle device which has a same resemblance as if someone is holding a paper. Naturally printing cost and distributions of books and novels creates a huge impact on their pricing strategies. Contrary on the other hand, Kindle offers same products at a very less price because all the books are synchronised in their cloud services. It is just a matter of time when a consumer pays money books are synced on their Kindle home page. Delivery time and cost are nearly zero and it is a Win-Win game for Amazon company, consumers and writers. It was just a matter of time that Kindle gathered greater market share as compared to the print media(hardcover books).

It is now estimated that in 5 years every member of generation $\mathrm{Z}$ will have an Amazon Kindle instead of actual printed material. Amazon with their intelligent marketing strategies and PR created a scenario in which holding a Kindle is a significance of knowledge. Furthermore, They pushed their consumers to buy more Kindle devices at lower rates. It's a loss leader pricing strategy in which they are offering device at lower cost but they will earn from selling books, newspaper and novels.

\section{Chapter 1.2 VR Product testing}

When dot com bubble bursts there are many E-Commerce industries. However, they grab a very little share of the market. Many E-Commerce platforms do not sell technologically high-end products but they managed to create a new VR experience on their website and apps. This VR and augmented reality created a huge buzz and went viral in no time.

One of the good examples for this argument is lenskart.com. Lens kart is a multi-million industry in India whose business is selling spectacles and sunglasses in Indian market. They have introduced a concept of virtual reality on their website which allows consumer to see how they look when they will be wearing that particular frame or sunglass. This technological advancement was heavily marketed and company even hired one of the topmost Bollywood actress Katrina Kaif to promote their virtual reality program. I would like to emphasize on the point that marketing on virtual reality does not imply that their frames and sunglasses are high end and they will last longer. However, it drives or creates a desire to explore (in the minds of consumer). Certainly, this virtual reality enhances leads which eventually create more revenue for the company. We can also agree on the fact that alone VR is not responsible for the revenues. The companies even focused on their price points, promotional offers and loyalty programs to retain consumer base. Even now many apparels and FMCG industries have been using virtual reality in their shopping malls and retail outlets to increase the amount of foot fall

\section{Chapter 1.3 Artificial Intelligence}

Artificial intelligence is one of the biggest innovations in the history of computers as it has ability to think and make decisions just like a human being with certain constraints and available parameters. This was no surprise that this technology had created a huge impact on industries in many aspects. Now artificial intelligence is being used in manufacturing plants, human resources, resource and development departments and even in marketing. Many social networking sites such as Facebook, Google and Yahoo have deployed artificial 
Website: ijetms.in Issue:4, Volume No.4, July-2020 DOI: 10.46647/ijetms.2020.v04i04.001

intelligence to enhance interaction. In this report, we are not considering any of the technical or IT industries because it is obvious for them to create high end products with new features and advancement to retain their consumer rather we are selecting those industries which have nothing to do with artificial intelligence, robots or virtual reality whatsoever but they have managed to enhance their brand image with the help of emerging technologies.

Many premium and luxury car manufacturers such as MG, BMW, Audi and Rolls-Royce have included artificial intelligence in their cars. it is obvious that the price point for these cars are very high and till now it is considered as luxury. In Indian market, MG launched HECTOR with an artificial technology enabled under the name of "HELLO MG". This AI has also video and audio streaming features. Consumer have access to music library of millions of songs.

This created a huge impact on the market and in less than no time it became a real competitor of Tata motors and Jeep. Tata motors and Jeep have their flagship variants under the name of HARRIER and COMPASS but they lack in artificial enabled system and auto-driving assistance. MG hectare with the same price. Managed to sell more cars as compared to Tata harrier and Jeep compass.

Many companies such as policy Bazzar and Zomato incorporated AI enabled chat bots. These chat bots reduce reaction time and increases customer satisfaction. Earlier companies have to manage huge customer support staff. This staff also does not work for 24 hours and 365 days. On the other hand, chat bots can operate seamlessly and it is also cheap to install them.

In 2010 dominos launched DXP where advanced technologies were introduced for delivering pizza such as self-driving car. In 2008, dominos even introduced a pizza tracker technology which enables consumer to track their pizza. This let people to follow the progress and it also shows an approximate time at which pizza will be delivered. Domino's was also the first company which rolled out voice ordering systems in their app which will directly order your favourite pizza and deliver it in less than 30 minutes. In 2016 Domino's even launched zero click ordering system in which all you have to do is to click a button and your favourite pizza will be delivered in less than 30 minutes. This single click feature was revolutionary in those days when Uber eats and Zomato were struggling in the market. In New Zealand, dominos was the first company among its competitors that were using remote controlled aircraft for delivery systems. In 2019 Domino's incorporated artificial intelligence in their customer loyalty program and they are committed to provide high tech feature in their pizza delivery systems.

Dominos rather focusing much on their products and increasing retail outlets they shifted their revenue stream in R\&D of robots and self-driving cars for delivering pizza. They were among the first companies which chose this trajectory to enhance their revenue. With the advanced technology in place Domino's managed to increase their profit margin and also self-driving cars and robots went viral in digital age. In not less than 10 years dominos beat pizza hut and became the highest grossing fast food chain in the world. Now, it's a popular saying that Domino's is a tech company which happens to deliver pizza.

\section{Chapter 1.4 Smart watches}

Smartwatch is a wearable computer form of a traditional wrist watch. the provide touch screen interface for daily uses and it also contains different apps such as calculator, media player, radio, Bluetooth headset, game playing and other fitness related applications. smart watches were initially launched by company called Fitbit, however it gained momentum and now it is made almost by every IT company. now they are powered by rechargeable lithium ion battery e and their screens are made up of OLED displays. Nowadays smartwatches contain GPS tracking unit coma LTE connections and they are powered by various operating system such as IOS and Android. There are extremely marketed in fitness industry as they are capable of tracking blood pressures, stress levels and calorie burnt in a day. gradually new angular designs and with the mobile interface advancements smartwatches appears same as that of traditional watches and they can even change their design off dial.

A craze for smartwatch is gradually increasing among teenagers because they look exactly same as some other high and traditional wrist watch and on the plus side they can do terms of different activities for the user. Good high and traditional wrist watch comes with a minimum price tag of rupees 15000 and high-end apples or Samsung gear S2 comes with a price tag of 20,000-30,000 depending upon its features. Smartwatch market is now nearly worth of 5 billion dollars and it's kept on increasing at a CAGR of $12 \%$. Every year major IT companies comes up with a new advanced and upgraded model of their watch and slowly smartwatch industry is above traditional wrist watch industry. even though many companies in wrist watches market themselves as a luxury product and their price points are at higher scale still smart watch industry is making way for itself at a very fast pace

\section{CHAPTER 2: RELATED WORK DONE}

The rapid advancements in automation and artificial intelligence is creating a huge impact on businesses. This industry uncovers the fact that advanced AI is disrupting the labour markets at a significant level. The study accepts the fact that $\mathrm{AI}$ and automation has profound impact on economies and increasing profit margins for businesses. Different perspectives related with automation is mentioned in (Frank et al., 2019) [1]

A study conducted by KPMG showed that mass if niches are increasing at very tremendous rates. Digital enthusiasts and sophisticates will be nearly more than 600 million by the year 
Website: ijetms.in Issue:4, Volume No.4, July-2020 DOI: 10.46647/ijetms.2020.v04i04.001

2030. They will have a yearly house hold income of more than $\$ 10,000$. This study will be very useful for our research paper and framework we are going to propose.(KPMG, 2019)[2]

(Jin \& Li, 2012) with the help of Nash equilibrium covers many scenarios and different aspects of business handling with respect to technology. It analyses the entire fact with the help of equations. In the conclusion they presented 8 corollaries with covers impact of major aspects of adoption of technology.[3]

(Balasubramanian, 1998) elaborates major differences between direct marketing and conventional retail marketing. In a recent study that shows that $68 \%$ millennials are shopping online. However, there are many fields where online shopping is not possible. It compares different marketing models. [4] (Delloite, 2013) beautifully describes the steps taken by Red Chillies Entertainment group to create a $300 \mathrm{Cr}$ film. The movie titles as "Chennai Express" is considered to be biggest blockbuster in the history of Indian cinema and this report explains the role of population analysis in mass media marketing. The report describes that online channel have very high impact on revenues. [5]

(Bower \& Christensen, 1995) explores that fact that technology is changing at a very fast rate. It emphasizes on the fact that even though a technology does not serve the purpose of mainstream market and consumer now but can be useful in future. This paper gave example of many companies such IBM and Nakia which underwent similar situation. It stresses on the fact that companies should keep one eye on current trends and another eye on future technology. [6]

(Jensen R, 1982) Business is all about uncertainty. It is not possible that every technology will excel in future. However, cost of building a technology is huge and so is uncertainty. This paper attempts to make decision-making tree which has high probability of being successful. This entire research is based on the fact that adoption of technology by a firm is not obstructed by its beliefsError! Reference source not found. (IFPI, 2019) a global community which represents entire recording industry worldwide. This report states that in music business grew by $46 \%$ in online streaming channel. This includes both paid and unpaid channels. However, physical streaming got decreased by $10.1 \%$ in last fiscal year. The report also showed data analysis._Error! Reference source not found.

In paper (Keisidou \& Sarigiannidis \& Maditinos, 2009) discusses various characteristics of consumer when buying online with respect to various products. The paper gives useful insights about various products such as books, subscription, TV sets, etc and they proved their concept with help of factor analysisError! Reference source not found.

In (Vidya \& Selvamani, 2018) consumer behaviour is identified in shopping(online). The results showed that out of all correspondents there was no link between earnings and level of satisfaction. It also identified that many respondents between 25-30 age have income nearly 20,000 rupeesError! Reference source not found.
(Kumar, 2017) identified a consumer perception towards smartwatches in to the part of a market. From a structured questionnaire they identified that nearly $48 \%$ people want a smartwatch as opposed to only $20 \%$ people who need it.[7]

(Carlos Martins Rodrigues Pinho \& Soares, 2011) have examined technology acceptance model which is a very good extension of TRA. They analysed on social networking websites. In (Bröhl \& Nelles \& Mertens \& Schlick, 2016), (Kim \& Shin, 2015) and (Manis \& Choi, 2019) they did technology acceptance model on VR, AI and Smart watches. All results are positive. $[12][13][14][15]$

In [16] CAGR of digital content market has been exponential has been proven in the paper. The paper throws light on incredible push on technology in media market. The paper also explains that compared to other(traditional sources) digital content is growing at tremendous rate.

The forecast of price-water-house-coopers for the year of 2010-2014 predicts that there will be CAGR of $5.0 \%$ as predicted in paper [17] (Shapiro \& Varian, 1999) A framework for strategic business decisions is much needed for policy makers and other business executive. The paper [18] is an attempt to solve the paper. This paper argues on the fact that although technology changes but rules of economics does not change.

(Asatiani, 2016) it is been long argued that size of technologically push market can be measured with the help of tangible assets such as $\mathrm{CD}$, VR, etc. however after the emergence of cloud computing its impact is humongous. This paper attempts to prove the same relationship. [19]

(Gotz, 2000), (Han , Kim \& Kim, 2001), (Hoppe, 2000) and (Huisman \& Kort, 2004) Adoption of emerging technology is a very complex decision because it evolves huge money outflow, change in human resources, change in advertising media, change in project and machinery financing. This decision is taken under huge uncertainties and confusions. It is also true that adoption of technology involve large outflow and little to no inflow of money during its commissioning, in paper [20][21][22][23][24]

Technology has huge impact on people life and it not only changes the way of operations but it also changes the thinking and management style of various companies. It also involves changing the mind set and operational way of promoters and board of directors. [25]

AI is not a new technology; it is present more than a decade now and it is crucial to identify the next destination of Artificial Intelligence. In [26] it identifies that all the threetechnology linked to artificial intelligence are machine learning, neural network and reinforcement learning are slowing coming to an end. These technologies have reached to their maximum level and will slowly come to end.

One of the greatest fields of mankind which is very essential for an economy is tax collection and law. Both the fields require tremendous amount of man hours and tons of brain storming sessions. If artificial intelligence could replace the so much of man hours and could do work in seconds then it will 
Website: ijetms.in Issue:4, Volume No.4, July-2020 DOI: 10.46647/ijetms.2020.v04i04.001

be the biggest victory of artificial intelligence. Use of artificial intelligence in the fields of automated tax calculations and tax collection is discussed in this paper. [27]

In [28] KPMG identified that robotic process automation and block chain has been in demand. It clear for the fact that artificial intelligence, automation and Virtual reality has soon come to an end. Even VFX has failing to create at impact on market because almost everybody is using it. Block chain and robotic process automation are still in its inception phase.

Our report requires newest tech trends to create a good understanding of these emerging trends. Delloite has created a new list of emerging trends in 2019 and it is available in [29]. Every generation has its own characteristics and it is obvious that their shopping preferences and perception differs from others. These trends should keep up with all generations and a good CRM software in place will surely help a lot [30]. Millennials are what we are totally focussing upon and in [31] they attempt to understand that how technology is important to millennials. It is what which reflects their class and what not. Also, in [32] impact of eco-friendly on consumer behaviour is mentioned. It is clear from the fact that technological products are environmentally friendly or for an instance it can be said that they are perceived as environmentally friendly. That is the reason for their tremendous boom [33][34].

What does a culture think right and wrong, products are generally accepted in that country in the same way? This fact is true and also contradicts its very core. It is been proved several times that perception has been changed by marketing. For example, 20 years ago water purifier is not acceptable by societies. It is often perceived as an instrument that weakens body structure and immune power. Similarly nestle Maggi was a product of west and there are small chances of east accepting it as a part of diet. Now Maggi is unbeatable king in FMCG industry in India. [35].

It is clear from the facts that movie making industry has already achieved its peak in product life cycle curve. It is now very difficult for various movie industry to keep up with trends. They have focussed on stories, screenplay, actors, sponsors, VFX and what not. Many movie industries such as Indian cinema also includes songs and dancing to increase consumer attention. However, in these papers movie strategies and promotions techniques are discussed. In my view point these points are not exhaustive in nature because movie represent the identity of a society and society as a whole is immensely diverse. Often movies come under controversies for creating a misinterpreting meaning from situation. This led to decline in consumer attention and often brand image of director, actors and crew is tampered which is very difficult to recover. [36][37]

Richard Schmalensee (1982), in research paper 'Product Differentiation Advantages of Pioneering Brands', presents and explores a relatively simple market model which rational buyer behaviour the face of imperfect information about product quality can give long-lived advantages to pioneering brands. In the basic model, brands enter sequentially, and consumers are initially skeptical about their quality.[38] When consumers become convinced that the first brand in any product class performs satisfactorily, that brand becomes the standard against which subsequent entrants are rationally judged.

M. Holbrook (1992) in paper 'Product Quality, Attributes, and Brand image as Determinants of Price: The Case of Consumer Electronics' proposes and illustrates an approach to measuring one aspect of brand equity, viewed as a price premium and defined as the increment that a brand name contributes to the price of a product above and beyond that justified by its quality (where quality is determined by assessment of the relevant attributes, features, or characteristics). [39]

Oliver (1999) Customer satisfaction has been one of the top tools for a successful business. Customer satisfaction is defined as an overall evaluation based on the total purchase and consumption experience with the good or service over time [40]

M. Delong (2004), can be stimulated by the knowledge about brand and customers tend to rely on the brand image they know already. Thus, marketers have an initial goal to construct the brand image that would entice consumers to purchase that particular brand. [41]

Robotic process automation is all-new technology. It is still under inception phase and has huge upside potential in industrial point of view. In simple words, Robotic process automation uses artificial intelligence to do simultaneous jobs. It has more complex and robust programming than any other machine learning algorithm. It is only meant for industries and is a completely new framework that is capable of doing several tasks all at once. A decentralised basis of bank also known as blockchain is also a very popular immerging technology in the world. Its inception took place in 2008, it instantly took off when a new privacy controls and complete security is talked about. It was design and created by set unknown people who became overnight sensation. Bitcoin transactions were off the charts and people became instant millionaires with this new technology in place.

\section{CHAPTER 3: DATA COLLECTION}

Primary data for the purpose of research will be collected in the form of a structured questionnaire from the regular computers and mobile phones users in various institutions and companies and also those who are using computers and mobile phones at their homes. Secondary data will get source from the literature reviews, companies' database, companies' websites and annual reports, journals and other publications.

In order to prove the fact that emerging technology has huge impact on consumer behaviour we have to collect data and analyse consumer sentiments online. For creating a framework, we need to collect data from various sources and identify them collectively so that we can easily establish the fact. For that we gathered data from three different sources: - 
Website: ijetms.in Issue:4, Volume No.4, July-2020 DOI: 10.46647/ijetms.2020.v04i04.001

1. Designing a survey

2. Sentimental analysis of tweets of selected products and companies

3. Analysing trends using google trends.

\section{CHAPTER 4: RESULTS}

1. Survey - Exploratory

a. Among all the 154 responses from the students it was been found that $83.1 \%$ consider themselves as digital enthusiast

b. $68.8 \%$ of them consider themselves as tech enthusiast

c. We asked to rate their excitement with the technology and digital world and it was found that more than $50 \%$ people work above 7 point

d. There was a mixed response related to online order of foods, groceries and other FMCG products however again nearly 50\% people were above 7 point

e. In Preferences between retail outlets and online ordering, there was a major trend towards online ordering.

f. Also, nearly $40 \%$ people stated that deep space missions are exciting

g. $\quad 65.6 \%$ people choose Amazon Kindle over hardback books and novels

h. $66.2 \%$ people said that it is exciting to have pizza delivered in drones or in self-driving cars

i. $83.1 \%$ people preferred to have car with artificial intelligence, automation and guiding systems

j. $82.5 \%$ people preferred car using clean energy

k. Nearly $68 \%$ people prefer to have products tested using VR and Augmented reality

2. Sentimental Analysis- Qualitative Analysis

a. For analysing two different car segments MG hectare has a mean sentiment of 0.27

b. Tata harrier has the same score of 0.27 however MG hectare is slightly greater considering rest of the decimal places

c. In the same segment Jeep compass has less sentiment, equal to 0.24

d. In the qualitative analysis, all the SUVs cannot be compared as there are only slight differences. Considering other parameters such as likes and retweets it is found that MG hectare is above all. e. In a comparison between Kindle and hardbound books, hardbound books are clear cut winner because they have more mean sentiment.

f. This analysis can be argued on the ground that there are many eBooks distributors and summing up all their sentiments will make them a clear winner

g. Printing of fresh hardbound book and its distribution is a costly. However, on the other hand eBooks has zero manufacturing cost and it is delivered in no time. As compared to margins still eBooks have greater advantage over hardbound books.

h. However, in a decision between Kindle and hardbound books. Qualitative analysis will also be considered.

i. Clean technology and products promoting green Revolution always have a high sentiment and green technology won by 0.77

j. In the pizza sector, pizza hut has more sentiments as compared to dominos but Domino's flagship programme DXP has sentiment equivalent to 0.54 which is very high.

k. The major reason behind domino's success was DXP program as it can be seen in sentimental analysis

1. Also, in a comparison between smart watches and wrist watches smart watches are clear cut winner with a mean sentiment of 0.5

m. As compared to the deep space missions such as basics, NASA and ISRO although excitement is high among media and citizens but their sentiments are less and is equal to 0.14. this is maybe because of the fact that space missions are very costly and controversial as many economists argue that search missions are not beneficial for mankind.

3. Google Trends Analysis- Qualitative Analysis

a. In the qualitative analysis $\mathrm{MG}$ hectare is a clear-cut winner as we have seen from the quantitative that all the three are nearly same so the one with more searches is a winner in this field.

b. In a comparison between Amazon Kindle and hardcover books Amazon Kindle is winner as hardcover books are searched nearly zero times. 
Website: ijetms.in Issue:4, Volume No.4, July-2020 DOI: 10.46647/ijetms.2020.v04i04.001

c. In a comparison between dominos and pizza hut, Domino's is superior in both qualitative and quantitative analysis.

d. In a comparison between smart watches and wrist watches, smartwatches surpass wrist watch in both qualitative and quantitative analysis.

From all the three types of test each and every aspect of a consumer behavior is verified and the first conclusion is that there is a huge impact of technology and inventions on the consumer behavior. This behavior is prominent in decision making process and drive consumers to purchase particular goods and services. In order to understand its impact on various aspects of a business we need tone big deeper and understand its impact on sales and revenue.

The entire project brings several conclusions which support the overall feasibility of the study. These conclusions also have impact on sales revenues. Initially it is clear from the data we have collected that advanced technologies (artificial intelligence, drones, robots and many more) have clear impact on customer's behavior in a positive way. It is very obvious that these technologies impact several parts of businesses(finance, operations, Human Resource and Marketing) but they have capacity to revive old loss-making industrial sectors. The entire conclusion is divided into 6 aspects which are capable of performing and overall study on the businesses.

\section{CHAPTER 5: CONCLUSION}

\subsection{Marketing funnel}

Traditionally, marketing funnel consists of four level based on principles of AIDA theory, it consists of awareness, attention, interest and action. Various studies have shown that people who are aware about the brand only $70 \%$ of them have desire to buy products and services offered by that particular brand. However only $30 \%$ people show interest in buying and among them only $5 \%$ people finally purchase that product or service. This funnel clearly shows that among all the people who are interested in the brand only $5 \%$ of them in the end make the final purchase.

In the new scenario proposed under this model for digital Enthusiasts and Sophists, loss of customers in awareness, desire and interest levels of this funnel will be reduced because consumers already have an affinity towards the brand and the products. In India, only disposable income and pricing strategy will create a huge impact on sales revenues. If price of the product is more than the disposable income of the consumer group it is very likely that they will not perform the action of purchase.

It is very clear from the industries which we have taken as an example. Lens Kart created its awareness program under the name of "try in 3D". In this program, it enables consumers to try their favorite frames and sunglasses online just by taking few pictures of their faces at different angles. To promoted this technology, they teamed with one of the most famous Bollywood celebrity Madam Katrina Kaif. I want to reiterate on the point that hiring a celebrity for this program and giving more attention to augmented product testing does not imply that the quality of the frames and sales will improve. However, this program was very successful in building up the empire which Lens Kart have.

Amazon with its prime delivery services includes robots, drones and aircrafts for home delivery in various countries. It not only increases the margin on the products but it also went viral on internet which eventually enable them to have free marketing for prime services.

With the same principle, Dominos launched its DMX program. It not only increases its margins but also increases consumers interest and attention on the type of deliveries they are doing. Eventually this interest leads to enormous increase in sales revenue. It is only the DMX program that helped Domino's to become world's biggest fast food company and it also beat its immediate rival pizza hut after 30 years.

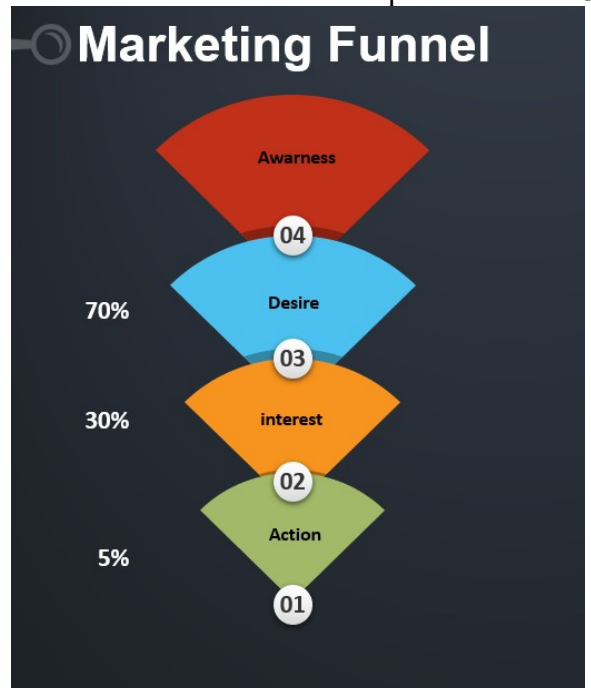

Figure 1: MARKETING FUNNEL 
Website: ijetms.in Issue:4, Volume No.4, July-2020 DOI: 10.46647/ijetms.2020.v04i04.001

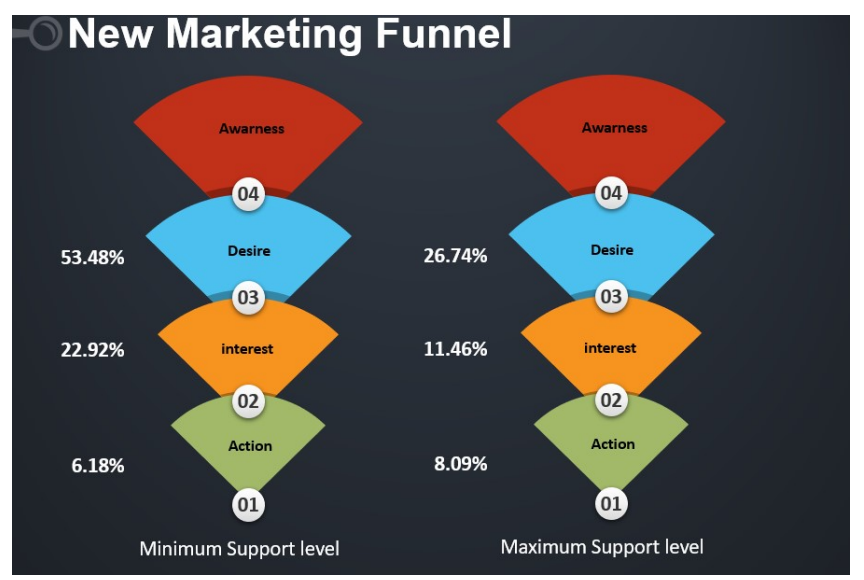

Figure 2: New marketing funnel

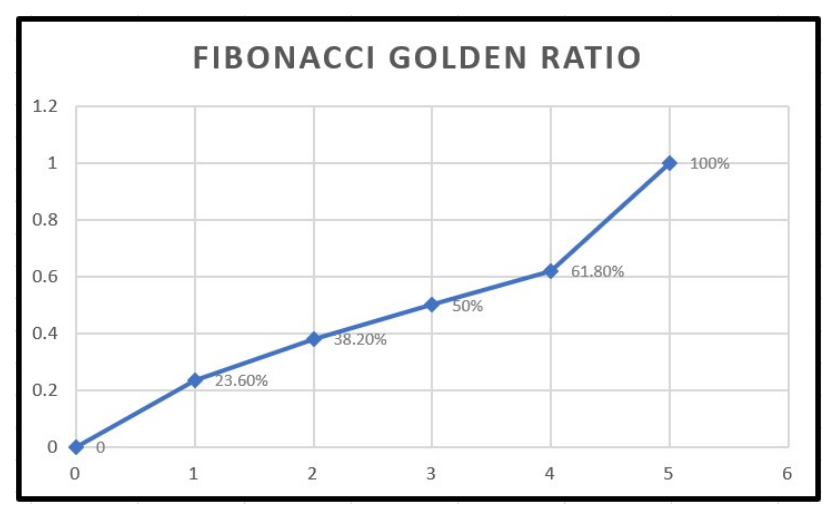

Figure 3: Fibonacci Golden Ratio

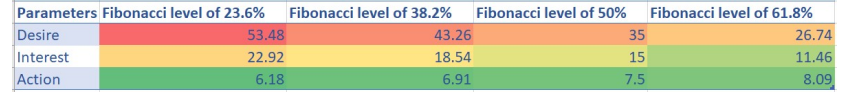

Figure 4: Fibonacci table

\subsection{Porter's five force model}

Porter's five force model was designed to identify and analyze various competitive forces that are essential for an industry. Porter's five force model in simple words describe the overall attractiveness of industry. this Framework has been used extensively by many forms to calculate its strategic position and it works with value chain analysis and other models to provide a bird's eye view for a business. In in the report we will be discussing on all the five competitive factors of porter's five force model

1. Bargaining Power Of Consumers

a. Earlier this sector is very much powerful and had a huge impact

b. After the deployment of technologies this factor loses its power because consumers have a neat desire and interest in the product which supersedes their bargaining power c. This factor also loses its momentum when perceived level of product differentiation increases

2. Power Of Suppliers

a. Suppliers do not have very much bargaining power because no other form can generate such a use amount of business as the given companies are generating.

b. This factor does not hold much power

3. Rivalry among various companies

a. Till now rivalry can be assumed as zero because with the examples we have there are very small direct rivalry to Domino's, Lens Kart, Amazon prime, smart watches and other sectors.

4. Availability Of Substitutes

a. There is practically no substitute available in the market because companies could file patents or have patent pending products and services.

5. Threat Of New Entrant

a. Threat of new entrants is also very low because deployment of such advanced technologies require huge amount of cash in hand and many companies does not have these types of resources.

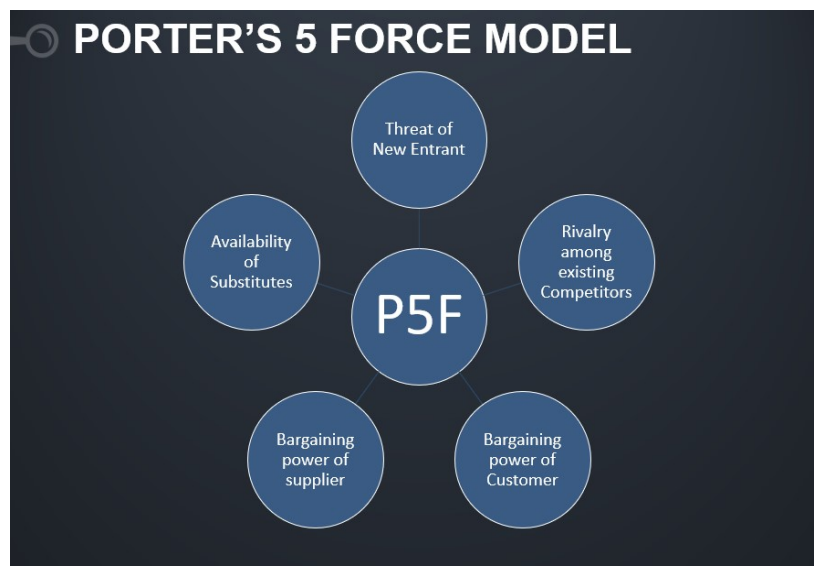

Figure 5: Old Porter's 5 force model 
Website: ijetms.in Issue:4, Volume No.4, July-2020 DOI: 10.46647/ijetms.2020.v04i04.001

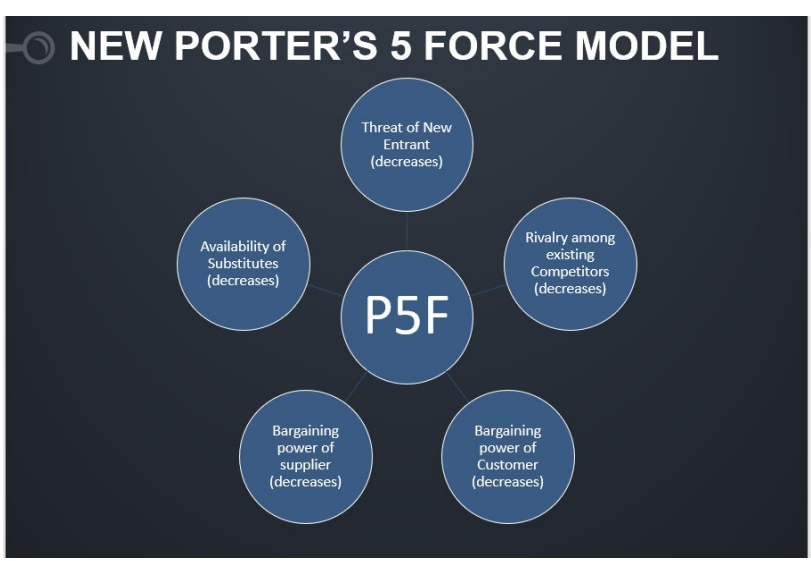

Figure 6: New Porter's 5 force model

\subsection{Promotion and Offers.}

Initially digital enthusiast might need some types of promotional offers so that they can purchase the product and services without giving second thoughts. This will be done initially in the launch phase just as a Kickstarter.

In later stages digital enthusiast does not need any type of monetary promotions rather only lesser price than competitor could suffice. Company can also make a promise of giving constant software updates and upgrades (only to a certain level) in all of their products. For example, One Plus introduced its red cable club.

It is very important to understand that product is a bridge between old school things and modern world. Additional discounts on accessories such as smart watch companies offer different patterns of wrist bands at a very low price.

Holiday sales, friends and family discounts and referral systems will increase the chances of purchase. It is also very crucial to understand that by huge amount of marketing is not necessary because the affection with the technologies will drive digital enthusiasts to purchase.

\begin{tabular}{|l|l|l|l|l|}
\hline $\begin{array}{l}\text { Consumer } \\
\text { Type }\end{array}$ & $\begin{array}{l}\text { Socio- } \\
\text { economic } \\
\text { profile }\end{array}$ & Language & $\begin{array}{l}\text { Primary } \\
\text { mode }\end{array}$ & $\begin{array}{l}\text { Prefered } \\
\text { media }\end{array}$ \\
\hline $\begin{array}{l}\text { Digital } \\
\text { sophisticates }\end{array}$ & $\begin{array}{l}\text { Cities, } \\
\text { Metros } \\
\text { and rich }\end{array}$ & $\begin{array}{l}\text { English, } \\
\text { hindi, } \\
\text { korean and } \\
\text { Italian }\end{array}$ & $\begin{array}{l}\text { Mobile, } \\
\text { smart TV, } \\
\text { laptop, } \\
\text { Tablets }\end{array}$ & $\begin{array}{l}\text { Global } \\
\text { content }\end{array}$ \\
\hline $\begin{array}{l}\text { Digital } \\
\text { Enthusiasts }\end{array}$ & $\begin{array}{l}\text { Same as } \\
\text { D.P. }\end{array}$ & $\begin{array}{l}\text { Hindi, } \\
\text { English } \\
\text { and } \\
\text { regional }\end{array}$ & $\begin{array}{l}\text { Smart } \\
\text { phones and } \\
\text { computers }\end{array}$ & $\begin{array}{l}\text { Indina } \\
\text { content }\end{array}$ \\
\hline $\begin{array}{l}\text { Digital } \\
\text { Mainstream }\end{array}$ & $\begin{array}{l}\text { Free } \\
\text { loaders }\end{array}$ & $\begin{array}{l}\text { Hindi and } \\
\text { regional }\end{array}$ & $\begin{array}{l}\text { Smart } \\
\text { phones }\end{array}$ & $\begin{array}{l}\text { Regional } \\
\text { content }\end{array}$ \\
\hline
\end{tabular}

Figure 7: Consumer type

\subsection{Pricing Strategy}

Pricing strategy will be very crucial because company need to cover up all the losses it bore in the past because of development of technology. It is clear that pricing should be higher as compared to other competitors but companies should aim to increase their mark-up value rather than the cost.

Also, it is very important for company to create a low-end product for digital mainstream consumers or in the simple word freeloaders. This free content given to freeloaders will ensure a constant increase in desire and interest of buying that particular product. Gradually a company can increase its restrictions on free content so that consumers are compelled to purchase.

Pricing strategy could be : -

- Premium

- Luxury

- Captive

- $\quad$ Skimming

\subsection{Consumer relationship}

Beyond any scope of doubt every industry who had or who will be deploying advanced grade technologies for their operational purposes will have to create a very effective consumer relationship platform.

In the case of digital enthusiasts and sophisticates it is very simple, easy and cost effective to create a consumer relationship platform. An online community platform is required which keeps on posting new features of the products and also offer special discounts to brand loyalists.

For example, one plus introduces its Red Cable community which offers various services such as battery change, screen repairing, speaker repairing and other services of a mobile phone at free of cost. The platform also reduces switching cost for other brand uses. Community must offer several services and accessories available at free or cheap rates for their members

Company can also make use of multiple checkouts, EMI options, one tap ordering, check-ups, other exclusive rights

\subsection{Segmentation}

Recently, a radical decrease in the price of smartphones, data plans and various digital payment options there is a boom in Indian economy for e-commerce. In 2030 it is estimated that India will have 850 million smartphones which will enable lower socio-economic classes to come forward. Leisure usually comes at a very high price. However, after the launch of smartphones it is found that there is a high consumption of films, music, social media content, digital games and many other online activities among the users

1. The Indian market will have enormous amounts of smartphones but there is very low provision for 
Website: ijetms.in Issue:4, Volume No.4, July-2020 DOI: 10.46647/ijetms.2020.v04i04.001

secondary devices such as tablets and laptops. it is very crucial for a company to make their applications and Web services mobile friendly in their digital media ecosystem

2. In the modern world, women constituted a majority of 1.4 billion people living in India. Because of decrease between the pay gaps of various genders and reduction in several cultural constraints now women have been actively involved in various online activities.

3. It is observed that audience in a digital ecosystem are sensitive towards hyper-local content and global content may not satisfied them. It is very crucial for a company to change its products and services from area to area

4. It is also very important to optimise social cultural factors which India predominantly possess among its consumption patterns

5. Drive for Digital media ecosystem is not free at all and it comes at a very high price. Company must focus on its core products and must not give free services to everyone.

\section{References}

[1] Frank, M., Autor, D., Bessen, J., Brynjolfsson, E., Cebrian, M., \& Deming, D. et al. (2019). Toward understanding the impact of artificial intelligence on labour. Proceedings Of The National Academy Of Sciences, 116(14), 6531-6539. doi: 10.1073/pnas.1900949116

[2] KPMG. (2019). India's digital future: Mass of niches. KPMG In India'S Media And Entertainment Report.

[3] Jin, B., \& Li, Y. (2012). Analysis of emerging technology adoption for the digital content market. Information Technology And Management, 13(3), 149-165. doi: 10.1007/s10799-011-0113-6

[4] Balasubramanian S (1998) Mail versus mall: a strategic analysis of competition between direct marketers and conventional retailers. Market Sci 17:181-195

[5] Delloite. (2013). CHENNAI EXPRESS CASE STUDY.

[6] Bower, J. L., and C. M. Christensen. "Disruptive Technologies: Catching the Wave." Harvard Business Review 73, no. 1 (JanuaryFebruary 1995): 43-53.

[7] Mahesh, Bhasutkar, Maninti Venkateswarlu, and M. Raghavendra. "End-to-end congestion control techniques for Router." 2011 International Conference on Communication Systems and Network Technologies. IEEE, 2011.

[8] Mahesh, B., and K. Shyam Sunder Reddy. "Router Aided Congestion Control Techniques." Second International Conference on Information Systems and Technology.

[9] Mahesh, B. "Dynamic Update and Public Auditing with Dispute Arbitration for Cloud Data." Journal of Advanced Database Management \& Systems 4.3 (2017): 14-19.

[10] Mahesh, B., et al. "A Review on Data Deduplication Techniques in Cloud." Embedded Systems and Artificial Intelligence. Springer, Singapore, 2020. 825-833.

[11] Kumar, D. (2017). Consumer Perception and Purchase Intention towards Smartwatches. IOSR Journal Of Business And Management, 19(01), 2628. doi: $10.9790 / 487 x-1901042628$
[12] Carlos Martins Rodrigues Pinho, J., \& Soares, A. (2011). Examining the technology acceptance model in the adoption of social networks. Journal Of Research In Interactive Marketing, 5(2/3), 116-129. doi: $10.1108 / 17505931111187767$

[13] Manis, K., \& Choi, D. (2019). The virtual reality hardware acceptance model (VR-HAM): Extending and individuating the technology acceptance model (TAM) for virtual reality hardware. Journal Of Business Research, 100, 503-513. doi: 10.1016/j.jbusres.2018.10.021

[14] Kim, K., \& Shin, D. (2015). An acceptance model for smart watches. Internet Research, 25(4), 527-541. doi: 10.1108/intr-05-20140126

[15] Bröhl, C., Nelles, J., Brandl, C., Mertens, A., \& Schlick, C. (2016). TAM Reloaded: A Technology Acceptance Model for Human-Robot Cooperation in Production Systems. HCI International 2016 - Posters' Extended Abstracts, 97-103. doi: 10.1007/978-3-319-40548-3_16

[16] Kim C, Oh E, Shin N (2010) An empirical investigation of digital content characteristics, value, and flow. J Comput Inform System 50(4):79-87.

[17] Global entertainment and media outlook 2010-2014 (2010)PricewaterhouseCoopers. Available at http://www.einnews.com/pr-news/90509-pricewaterhousecoopersreleases-global-entertainment-and-media-outlook-2010-2014.

[18] Shapiro C, Varian HR (1999) Information rules: a strategic guide to the network economy. Harvard Business Press, Boston

[19] Asatiani, Aleksandre. (2016). Impact of Cloud Computing on Business Process Outsourcing. 10.13140/RG.2.2.29591.16805.

[20] Gotz G (2000) Strategic timing of adoption of new technologies under uncertainty: a note. Int J Ind Organ 18(2):369-379

[21] Han JK, Kim N, Kim HB (2001) Entry barriers: a dull-, one-, or twoedged sword for incumbents? Unraveling the paradox from a contingency perspective. J Market 65(1):1-14

[22] Hoppe H (2000) Second-mover advantages in the strategic adoption of new technology under uncertainty. Int J Ind Organ 18(2):315-338

[23] Hoppe H (2002) The timing of new technology adoption: theoretical models and empirical evidence. Manch Sch 70(1):56-76

[24] Huisman K, Kort P (2004) Strategic technology adoption taking into account future technological improvements: a real options approach. Eur J Oper Res 159(3):705-728

[25] Cascio, W. and Montealegre, R. (2016). How Technology Is Changing Work and Organizations. Annual Review of Organizational Psychology and Organizational Behavior, 3(1), pp.349-375.

[26] Hao, K. (2020). We analysed 16,625 papers to figure out where AI is headed next. [online] MIT Technology Review. Available at: https://www.technologyreview.com/s/612768/we-analyzed-16625papers-to-figure-out-where-ai-is-headed-next/ [Accessed 22 Jan. 2020].

[27] The Verge. (2020). The state of AI in 2019. [online] Available at: https://www.theverge.com/2019/1/28/18197520/ai-artificialintelligence-machine-learning-computational-science [Accessed $22 \mathrm{Jan}$. 2020].

[28] KPMG International (2019). Millienials and technology leaders differ on top technologies for business transformation: KPMG report. KPMG International.

[29] Deloitte Consulting LLP (2019). Tech Trends 2019 : Beyond the digital frontier. Deloitte Consulting LLP.

[30] orden, g. (2015). Millennial (Gen Y) Consumer Behavior, Their Shopping Preferences and Perceptual Maps Associated With Brand Loyalty

[31] Tadena, N. (2015). For Millennials, Use of Technology Just as Important as Brand Name, Study Finds. [online] Available at: https://blogs.wsj.com/cmo/2015/01/27/for-millennials-use-oftechnology-just-as-important-as-brand-name-study-finds/ [Accessed 22 Jan. 2020].

[32] Sehgal, M. (2010). Impact of Eco-Friendly Products on Consumer. [online] 6. Available at: http://cbsmohali.org/img/chapter6.pdf [Accessed 22 Jan. 2020]. 
Website: ijetms.in Issue:4, Volume No.4, July-2020 DOI: 10.46647/ijetms.2020.v04i04.001

[33] Current trends in the consumer behaviour towards eco-friendly products. (2015). Economic and Environmental Studies, [online] 15. Available at: http://hdl.handle.net/10419/178880 [Accessed 22 Jan. 2020].

[34] Young, K. (2020). Consumer Behavior - What Drives Eco-Conscious User \& Customer Behavior?. [online] GlobalWebIndex Blog. Available at: $\quad$ https://blog.globalwebindex.com/chart-of-the-day/eco-consciousconsumer/

[35] Ellett, L. (2019). How are morals and values shaping consumer purchase decisions?. $\quad[\mathrm{Blog}] \quad$ Available at: https://home.kpmg/uk/en/home/media/press-releases/2019/11/how-aremorals-and-values-shaping-consumer-purchases-decisions.html [Accessed 22 Jan. 2020].

[36] Lane, D. and Husemann, E. (2004). Movie Marketing Strategy Formation with System Dynamics: Towards a multi-disciplinary adoption/diffusion theory of cinema-going. Komplexität und Dynamik als Herausforderung für das Management, pp.179-222.

[37] Victoria, a. (2020). Digital marketing strategies for next generation film distribution. International journal of film and media arts

[38] Richard Schmalensee, American Economic Review, 1982, vol. 72, issue 3, 349-65

[39] Arjun Chaudhuri and Morris B. Holbrook, Journal of Marketing, Vol. 65, No. 2 (Apr., 2001), pp. 81-93

[40] Richard L. Oliver, Journal of Marketing, Vol. 63, Fundamental Issues and Directions for Marketing (1999), pp. 33-44

[41] Neupane, Ramesh. (2015). The Effects of Brand Image on Customer Satisfaction and Loyalty Intention in Retail Super Market Chain UK. International Journal of Social Sciences and Management. 2. 10.3126/ijssm.v2i1.11814.

[42] Hofmann, Peter \& Samp, Caroline \& Urbach, Nils. (2019). Robotic Process Automation. Electronic Markets. DOI: 10.1007/s12525-01900365-8. 